\title{
Does Green Public Procurement Lead to Life Cycle Costing adoption?
}

\section{Abstract}

Life Cycle Costing (LCC) is rarely used in public procurement, and public institutions have yet to fully understand its potential value for sustainable procurement. The new European Directive on Public Procurement is, however, designed to position LCC as central to sustainable sourcing.

Although previous studies have identified positive correlations between Green Public Procurement Policies (GPP) and LCC, it is still unclear how public institutions can further adopt LCC practices by leveraging their experience of green sourcing.

In this study, an organizational learning theoretical perspective is taken to investigate the circumstances under which public administrations' experience of GPP considered as a way of integrating the dimension of environmental sustainability into the sourcing process - stimulates their LCC learning and capabilities - considered as a way to include the sustainability economic dimension. The goal is to understand if the adoption of GPP can stimulate the internalisation of LCC in public tenders.

A multinomial logistic regression was conducted using a sample of 120 public administrations located in different countries. The results show that experience of GPP stimulates the internalisation of LCC at a public level, but only under specific conditions. The study contributes to the Sustainable Supply Management literature, being one of the first studies in the field adopting an organizational learning theoretical lens to review the role of experience as significant opportunity to develop capabilities. It also contributes to the organizational learning theory, by confirming that experience can aid learning but only in specific environmental contexts.

Keywords: Life Cycle Costing in the public sector; Green Public Procurement; Organizational Learning, Sustainable Supply Management. 


\section{Introduction}

Sustainable Supply Management (SSM) has been defined as "the extent to which supply management incorporates environmental, social, and economic value into the selection, evaluation and management of its supply base" (Giunipero et al. 2012, p.260), and thus encompasses the key "triple bottom line" concept (Carter and Rogers, 2008). Scholars agree that purchasing is the process with the most potential to address sustainability within supply chain management (Ashby et al., 2012). The SSM literature focuses more on the specific combination of environmental and economic perspectives in the procurement process, highlighting the need for their effective integration, and provides evidence for potential mutual benefits (Large and Gimenez Thomsen, 2011). Nevertheless, despite the growing interest of scholars in sustainable procurement (Walker and Phillips, 2008; Schneider and Wallenburg, 2012), there is still little understanding of how public institutions can successfully combine both economic and environmental perspectives when sourcing goods and services.

From an economic perspective, public institutions can use Life Cycle Costing (LCC) to calculate all costs of a product or service through the whole lifespan (Heijungs et al., 2013). Dragos and Neamtu (2013) underline the new role played by LCC as an innovative and central sustainable sourcing instrument used in public purchases, strengthened by recent regulations. Although the implementation of LCC can provide benefits (European Commission, 2016; Heralova, 2014), Dragos and Neamtu (2013) identify the challenges still faced by public institution decision-makers in systematically adopting LCC.

EU Member States have also recently begun applying green public procurement (GPP), which involves including green criteria in public procurement and is aimed at achieving "desirable environmental outputs and to promote green services and products by using public procurement" (Cheng et al., 2018, p. 771).

Numerous analyses of GPP practices have been conducted at different levels (Nikolaou and Loizou, 2015; Preuss and Walker, 2011; Testa et al, 2016a; Testa et al. 2016b; Uttam et al., 2013), but the use of LCC within these practices has rarely been explored (Heralova, 2014; PWC, 2009; Renda et al., 2012). A strong link has been identified between the environmental dimension of GPP and the economic dimension of LCC, which are both crucial in Sustainable Supply Management. However, no comprehensive analysis of this interaction has been conducted so far. We address this 
by taking an organizational learning theory perspective in our investigation of the relationship between GPP and LCC.

Sustainable procurement and supply management have rarely been examined from an organizational learning perspective in the literature. The seminal papers by Hult et al. (2000; 2003) focus on the strategic role played by organizational learning in purchasing management. Their results indicate that organizational learning positively influences knowledge, processes and performance in the context of supply management. However, these studies provide no additional insights in terms of sustainable procurement. Carter (2005) applies this perspective by considering the social element in purchasing, by investigating the role of organizational learning as a mediator between socially responsible supply management activities and the cost performance of the buying organization. The results suggest that firms must learn effectively from their socially responsible purchasing activities, with the aim of increasing supplier performance and eventually decreasing their costs. Similar studies that highlight the role of organizational learning in reconciling environmental and economic perspectives would also be of value, but as yet, the relationship between these two topics has not been examined, despite the increasing importance of GPP and LCC in recent environmental policies.

Public institutions can thus consider the possibility of developing the capabilities to successfully implement LCC practices, by leveraging previous experience in sustainable sourcing (e.g., GPP). It is, however, still unclear which contexts favour the development of such an integrated approach and can facilitate organizational learning. The rationale to study the impact that GPP experience may have to stimulate the LCC adoption is that, according to the organizational literature on experience and learning, if antecedent conditions are similar, experience on a task tends to be generalized in similar activities (Haleblian and Finkelstein, 1999). GPP and LCC are different approaches, but as they are both key components of an organization's sustainability culture they may have similarities. The literature on organizational experience and learning suggests that the process of generalizing experiences can improve a specific experience through knowledge. We therefore investigate whether GPP experience can stimulate capabilities in the more restricted area of LCC and encourage public administrations to adopt LCC.

The paper is structured as follows. First, the theoretical backgrounds of LCC and GPP are discussed. We then introduce the organizational learning theory, which is 
used to develop the conceptual framework and the hypotheses of the study. After discussing our research design, we present and discuss the findings. Finally, the conclusion, indications of the study's limitations and future research opportunities are presented.

\section{Theoretical background}

\subsection{Life Cycle Costing in purchasing management}

White and Ostwald (1976) define LCC as a method of correctly calculating the total amount spent on an item 'from its conception and fabrication through its operation to the end of its useful life'.

LCC has mainly been implemented at a private level, particularly in the construction sector (Chiurugwi et al., 2010; D'Incognito et al., 2015), and aims to 'optimise the cost of acquiring, owning and operating physical assets over their useful lives by attempting to identify and quantify all the significant costs involved in that life' (Woodward, 1997, p.336). This approach quantifies a number of options with the objective of defining the optimum selection of goods by taking into account all associated costs and is considered equivalent to Total Cost of Ownership (TCO) (Ellram, 1993).

Through the framework of public procurement, Costantino et al. (2012) developed a total cost of purchasing approach, aimed at minimizing total costs and thus focusing only on economic elements. TCO is an established concept in the supply chain and logistics management literature, but environmental and social dimensions are rarely considered in TCO-related research, although Oruezabala and Rico (2012) conducted their study in the public hospital context.

LCC can be applied in different ways and typically includes three types of assessment: conventional, societal, and environmental (Hunkeler et al., 2008). Conventional LCC refers to traditional financial assessment, including organization costs. Societal LCC also considers externalities through the internalization of social and environmental costs. Environmental LCC (ELCC) is a life cycle assessment approach that considers costs ascribed to different stakeholders (Martinez-Sanchez et al., 2015), including future generations, and the evaluation of "environmental externalities" (Dragos and Neamtu, 2013).

LCC can also be implemented from several perspectives (Iraldo et al., 2016). From a manufacturer's perspective, LCC can help to estimate future costs (Woodward, 1997), pricing (Horngren et al., 2012), and design aims (Asiedu and Gu, 1998), or to monitor 
costs or make decisions (Hasan, 1999; Lindholm and Suomala, 2004; Lindholm and Suomala, 2007). From this perspective, costs that are paid by the producer during the entire product life are considered in LCC. From a user's perspective, LCC involves the total costs sustained by a customer in buying, using, maintaining and disposing of a product (Woodward, 1997), and included in its final purchase price. LCC can also be adopted from a social perspective (Ogden et al., 2004).

Recent European policies have confirmed the significance of LCC by explicitly introducing it into public procurement practices. The 2014/24/EU Directive on Public Procurement radically changed the process of awarding tenders by recognising the importance of LCC. This Directive establishes that the most economically advantageous tender will be identified by applying a cost-effectiveness approach such as LCC.

A full implementation of the LCC approach in procurement procedures, therefore, means that all costs incurred during the life of a product or service are evaluated: i.e., purchasing and related costs (e.g., delivery, installation and insurance), future operating costs (e.g., maintenance, fuel, energy, water use and spares) and end of life costs (e.g., decommissioning, dismantling and disposal). By adopting LCC, public authorities consider all the use, maintenance and disposal costs of a resource that are not included in the purchase price (European Commission, 2016). By evaluating all the life-cycle costs of goods or services, the public sector may potentially achieve a high level of efficiency in the procurement process, as all the relevant direct and indirect costs sustained are included in procurement decision-making. Thus, public administrations may efficiently select from competing products and services, and all costs are expressed in consistent and comparable quantities (Heralova, 2014). LCC adoption can create a cost-efficient situation, as public authorities can compare alternatives based on overall cost, and accurately quantify any 'hidden costs' that can occur later, when the product or service is used. This enables public authorities to achieve cost savings and efficiency gains, leading to a 'win-win' situation: a greener product or service can also turn out to be cheaper if the overall cost across the whole life cycle is considered (European Commission, 2016). Savings can then be gained not only in terms of energy, water and fuel use, but also in maintenance, replacement and disposal costs. A LCC approach can thus be effectively implemented through its proactive and extensive adoption in procurement procedures.

Despite these benefits and the actions of regulatory authorities, little attention has been 
paid by scholars and practitioners to the real implementation of LCC by the public sector. The interaction between LCC and other sustainable procurement approaches such as Green Public Procurement is still unclear, as is how economic and environmental dimensions can be integrated to facilitate this 'win-win' outcome.

\subsubsection{LCC adoption}

Dragos and Neamtu (2013) acknowledge that adopting LCC is not an easy task. The broader LCC literature mainly investigates its implementation at a private level. Chiurugwi et al. (2010) found that about half the firms who participated in their study and were operating in the UK construction sector did not apply LCC. Similarly, Arja et al. (2009) and Olubodun at al. (2010) found a very low level of LCC adoption in the construction sector. Swaffield and McDonald's (2008) investigation into the use of LCC in private finance projects in the UK found that contractors do not use LCC in their procurements. Another recent study confirmed that LCC is very rarely applied in the UK construction sector (Higham et al., 2015).

From the perspective of practitioners, the survey by Renda et al. (2012) found that LCC is very seldom used by public authorities, as purchasing cost is the most widely used (if not the only) criterion. Similarly, a study carried out in EU Member States by PWC (2009) found that public bodies rarely adopt LCC.

Currently, successful LCC adoption is limited to a few cases. For example, in Italy the National Procurement Agency launched a framework contract to link cost savings and incentives for innovation in public purchases (European Commission, 2012). The Kolding City Council of Denmark issued an invitation to tender for supply contracts for energy efficient LEDs, based on the LCC method (European Commission, 2012). A survey conducted in the Czech Republic found that even if public authorities attribute importance to LCC at a strategic level, they do not consider it when choosing their operational approach for procurement (Heralova, 2014).

\subsubsection{LCC barriers}

The literature shows that several barriers limit the inclusion of LCC in public procurement procedures. The numerous constraints on public authorities can be regarded as internal factors hindering LCC use. Factors outside organizations can also impose external constraints. A summary of the barriers affecting LCC in public organizations is provided in Table 1. 


\begin{tabular}{|c|c|c|}
\hline Type of barriers & Barrier description & Source \\
\hline \multirow{7}{*}{$\begin{array}{l}\text { Internal to the } \\
\text { organization }\end{array}$} & Human resources & Assaf et al., 2002 \\
\hline & Lack of awareness from practitioners & Higham et al., 2015 \\
\hline & $\begin{array}{l}\text { Lack of familiarity with the concept of } \\
\text { LCC itself }\end{array}$ & Lindholm and Suomala, 2005 \\
\hline & Lack of staff skills & Chiurugwi et al., 2010 \\
\hline & Resistance to change & Christmann and Taylor, 2006 \\
\hline & Resistance to innovations & Damanpour and Schneider, 2009 \\
\hline & Resource scarcity & $\begin{array}{l}\text { Berry et al., 1999; Chackerian and } \\
\text { Mavima, } 2000\end{array}$ \\
\hline \multirow{5}{*}{$\begin{array}{l}\text { External to the } \\
\text { organization }\end{array}$} & Lack of clarity regarding LCC & \multirow{3}{*}{$\begin{array}{l}\text { Ardit and Messiha, 1999; } \\
\text { Dragos and Neamtu, } 2013\end{array}$} \\
\hline & Lack of fiscal incentives & \\
\hline & Lack of reliable data to support LCC & \\
\hline & $\begin{array}{l}\text { Lack of common methods to guide its } \\
\text { adoption process }\end{array}$ & $\begin{array}{l}\text { Chiurugwi et al., 2010; Higham et } \\
\text { al., } 2015\end{array}$ \\
\hline & $\begin{array}{l}\text { Uncertainty regarding the benefits } \\
\text { linked to LCC }\end{array}$ & Lindholm and Suomala, 2005 \\
\hline
\end{tabular}

Table 1 - Barriers to LCC adoption in public institutions

\subsection{The role of Green Public Procurement and the interface with LCC}

Bouwer et al. (2005) define GPP as a way used by the public sector to include environmental criteria in all phases of purchasing, by searching and choosing solutions with the least impact on the environment throughout the life cycle of products, and by encouraging the distribution of environmental technologies and the development of environmentally friendly goods.

GPP is becoming central to policies at European and at national levels (Tukker et al., 2008). Awareness of the importance of GPP in terms of sustainable consumption and production greatly increased after the United Nations Conference on Environment and Development in 1992. As public expenditure becomes increasingly important in the market (Gormly, 2014), GPP can help to achieve the market-oriented targets set by the European 2020 Strategy, including the minimisation of CO2 emissions and greater energy efficiency.

The potential environmental benefits of GPP are higher if green criteria are included in public bids (Parikka-Alhola, 2008). Testa et al. (2016b) pointed out that extensive knowledge of GPP tools, and a high level of public employee involvement, increase 
the probability of developing GPP practices. GPP thus cannot be considered as being merely the inclusion of green criteria in purchasing procedures. It is not only an operational activity, but should also reflect a clear strategy of any public authority for implementing policies to support the sustainable growth of the economic system.

The implementation of a LCC perspective in public tenders can also enable economic and environmental dimensions to be combined in sourcing (Hunkeler and Rebitzer, 2003), and as mentioned, can effectively help determine the lowest cost by evaluating offers comprehensively and thoroughly. However, the adoption of GPP does not necessarily imply taking a life cycle perspective. As noted, the two concepts are not necessarily interlinked, because organizations mainly consider the purchasing cost and do not always evaluate offers that take into account the total costs of a product throughout its life (Hunkeler and Rebitzer, 2003; Renda et al., 2012; Testa et al. 2016b). For example, Renda et al. (2012) showed that the purchasing cost is typically used in green public tenders. Testa et al. 2016b, analysed tenders in the building and construction sector considering green criteria. They found that criteria based on a life cycle perspective are rarely used but are statistically correlated to the greenness of a tender. This implies that the most compliant tenders, which include a life cycle approach, are more likely to be issued by public organizations that are more experienced and aware of GPP.

Considering this framework, and based on the organizational learning view that experience of a topic can stimulate knowledge in related areas, we expect that experience of GPP may positively affect LCC capabilities. The theoretical background is summarized in Figure 1. 


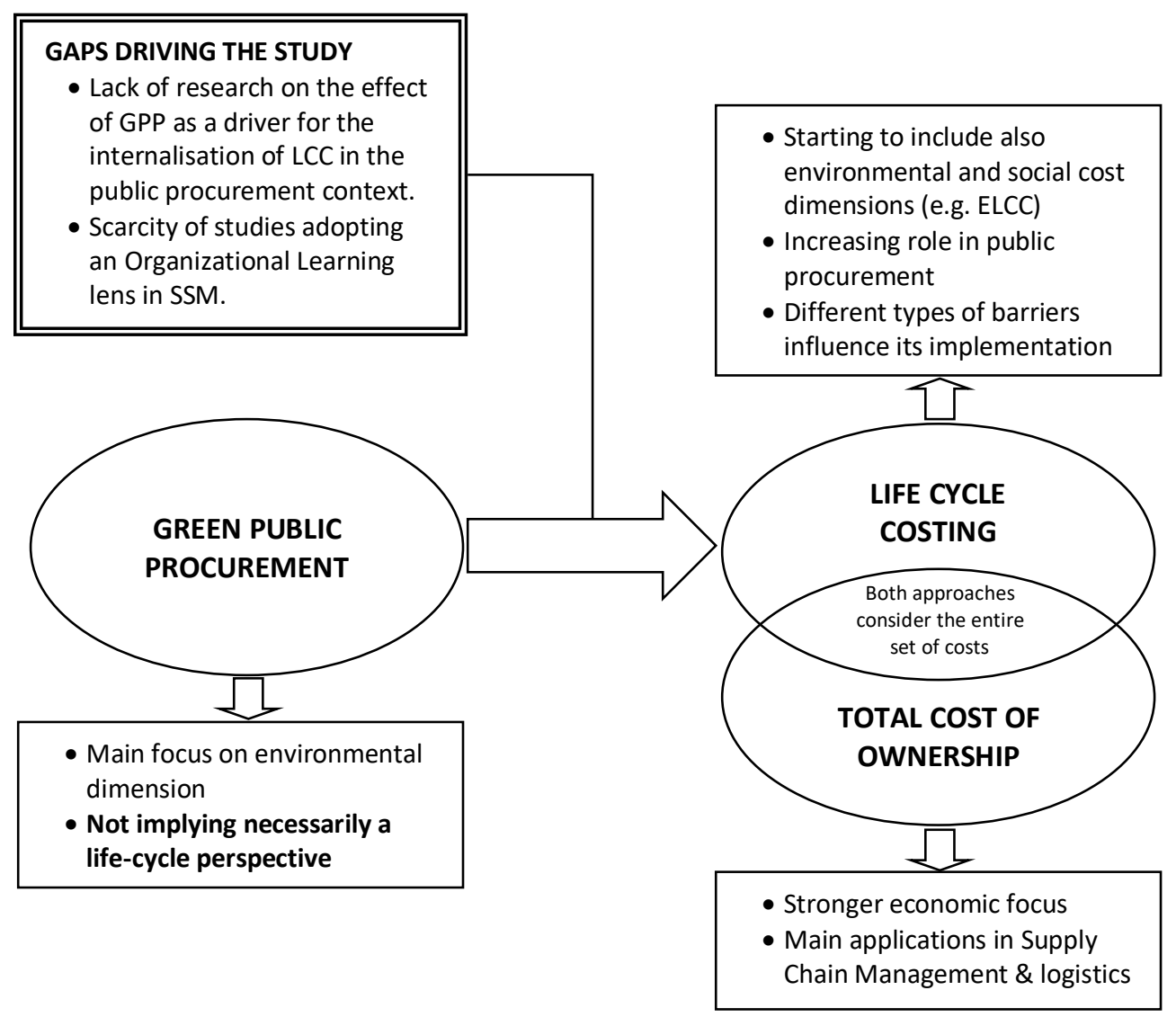

Figure 1 - Relationships between GPP, LCC and TCO

\subsection{Theoretical framework of organizational learning and hypotheses development}

In organizational learning theory, the experiences of task performance in an organization are converted into knowledge that can influence future experience and learning (Argote and Miron-Spektor, 2011; Huber, 1991; Levitt and March, 1988; Schilling and Kluge, 2009). Knowledge can be expressed via practices, tools or routines, but it can also be embedded in the organization's members. Organizational learning is a process of change (Dodgson, 1993) that takes place when organizations acquire experience (Argote and Miron-Spektor, 2011; Weiss, 1990), but can also be a result, in terms of modified knowledge (Dodgson, 1993). Learning experiences can involve individuals and groups and can result in the improvement of organizational outcomes. These experiences become part of organizational routines, processes and structure, and then influence the future learning of the members (Schilling and Kluge, 2009). 
By taking an organizational learning theoretical perspective, we aim to investigate whether experience of GPP can stimulate learning and capabilities for LCC. We also aim to establish whether this new knowledge can increase the likelihood that public administrations integrate and internalize LCC in public tenders. As Figure 2 shows, we develop the conceptual framework based on that of Argote and Miron-Spektor (2011). The organizational learning process occurs in an interactive context characterized by several components. Knowledge generated by previous experience of GPP influences the internalization of LCC, and thus its implementation (i.e., members implementing LCC and related tools). The learning process can be influenced by the environmental context (Fiol and Lyles, 1985) in which the organization operates, and a combination of experience and context produces knowledge (Argote and Miron-Spektor, 2011). Learning can be also affected by barriers (Schilling and Kluge, 2009), which can be viewed as part of the broader environmental context (Schilling and Kluge, 2009). An organization's environmental context has both external and internal aspects. External aspects include institutions, regulators, customers, and institutions, while internal aspects include factors such as culture, identity and strategy, which help define the internal boundaries of the organization. In summary, the organizational learning theory thus suggests that experience, tasks, tools, members of organizations and the environmental context interact to create knowledge.

Although the theory suggests experience has a positive effect on learning, it can also be regarded as an 'imperfect teacher' (March, 2010; p. 104), mainly due to the challenges and barriers mentioned that can be part of the environment in which organizations operate (Schilling and Kluge, 2009). These can have various effects on the learning process (Fiol and Lyles, 1985; Lam, 2000). In an extremely favourable environmental context that is stable and predictable, new additional learning will not take place and organizations do not act to change, as the incentive is low (Fiol and Lyles, 1985). Thus, in a favourable context characterized by low barriers and constraints, and where a certain level of learning and capability is already developed, additional change and learning will not occur (Fiol and Lyles, 1985). We expect that experience alone will not contribute to the further development of additional experience and learning. Thus, in this case experience is not translated into effective change (Fiol and Lyles, 1985). 
In a complex context, organizational learning may not take place (Fiol and Lyles, 1985; Lawrence and Dyer, 1983). In a turbulent environment learning and change are required (Fiol and Lyles, 1985), but the capability to learn may be limited, due to the existence of barriers and constraints. Some organizational learning theory scholars suggest that change and learning is a process through which organizations adapt to the context (Fiol and Lyles, 1985). Starting from this perspective, we expect that experience can stimulate learning and capabilities, contribute to overcoming existing barriers and allow the development of future experience and learning. Based on this theoretical framework, we investigate whether and under which conditions public administrations' experience of GPP stimulates their organizational learning and capabilities in terms of LCC, and, as a consequence if the likelihood that LCC is internalised in public tender procedures can increase.

For public administrations that operate in a favourable context where low barriers to LCC exist, we do not expect a higher level of GPP experience to be sufficient to contribute to further LCC experience and learning, or to stimulate these organizations to change. The outcome will be that they are reluctant to include LCC in public tenders. We thus hypothesise that:

H1: The higher the level of an organization's GPP experience, the higher the likelihood it will not internalize LCC through learning and specific capabilities, in the presence of low barriers.

By taking the view that learning begins with experience (Danneels, 2002; MacCormack et al., 2001) and that capabilities are built through experience (Arrow, 1962), we expect that a higher level of GPP experience in public administrations will positively affect LCC learning and capabilities, and will be important in overcoming high barriers to LCC implementation. The outcome will be increased opportunities for organizations to include LCC in public tenders, due to the learning and capabilities developed through their GPP experience. We can thus formulate the second hypothesis of the study:

H2: The higher the level of an organization's GPP experience, the higher the likelihood it will internalize LCC through learning and specific capabilities, in the presence of high barriers. 


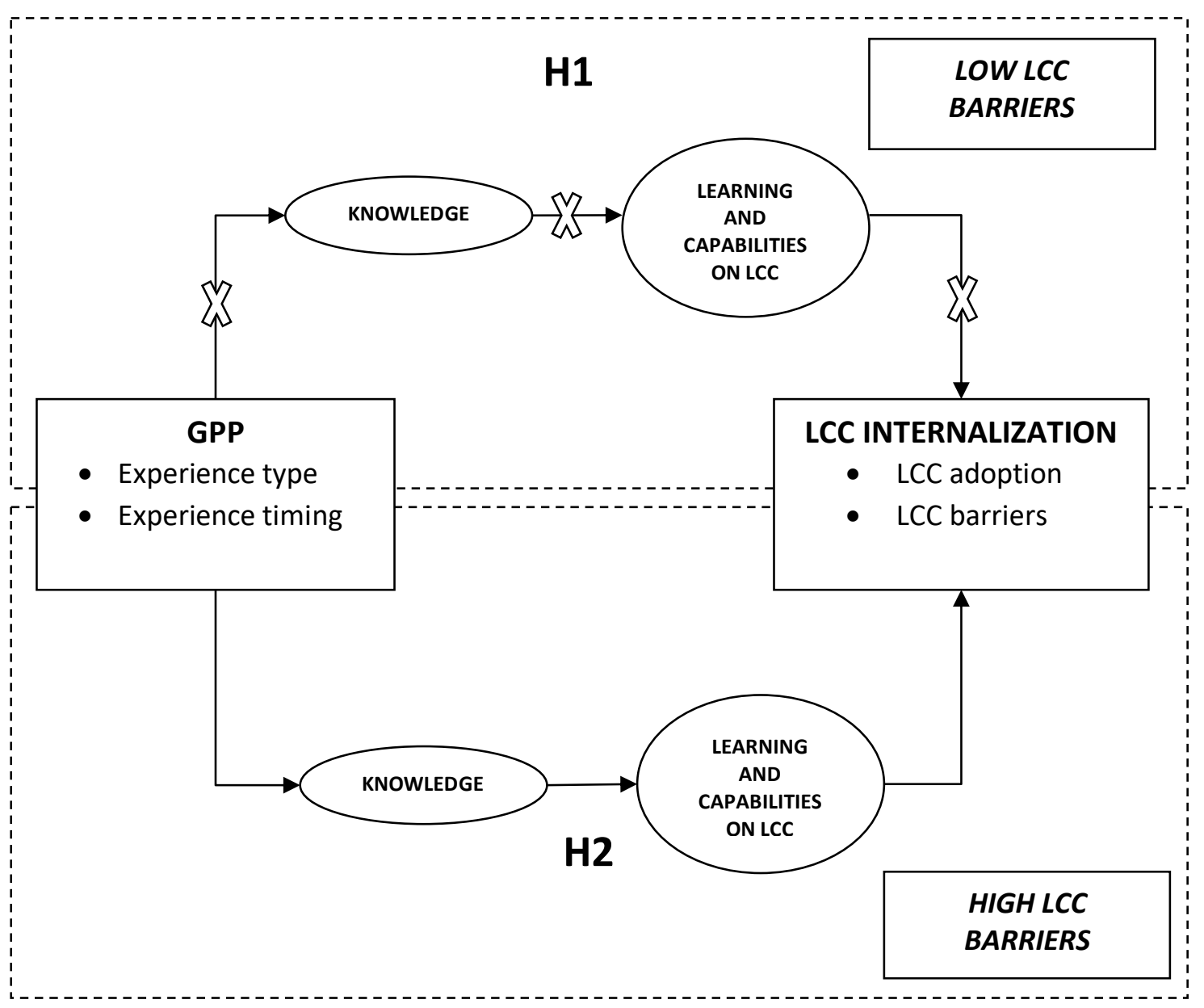

Figure 2 - Conceptual framework

We study the relationship between GPP experience and LCC learning by considering the type and timing of the experience. These features have been recognized as key to the relationship between firm experience and capabilities (Eggers, 2012). The breadth of experience can also be important for learning (Levitt and March, 1998; Huber, 1991).

In terms of experience type, we focused our study on the breadth and depth of public organization's experience (Holmqvist, 2004; Salvato, 2009) on GPP, meaning that public organizations apply GPP to different types of products or services (breadth) and to a high number of procurements (depth), (Eggers, 2012). In terms of timing, we consider the years of experience public organizations have in GPP, to investigate the effects of long-term GPP experience (Eggers, 2012). 
We define four profiles corresponding to four levels of LCC internalisation, as shown in Figure 3, by cross-analysing the level of LCC adoption and the intensity of contextual barriers that can prevent its implementation. The aim is to understand how previous GPP experience influences the probability a firm will increase its level of LCC internalisation, if barriers are equal or decreasing.

We first account for the different levels of LCC adoption. The level of adoption is deemed to be full and extensive when public organizations incorporate a LCC approach into the purchasing of specific products or services, or when they regularly implement LCC in their procurement procedures (i.e., in more than $50 \%$ of public tenders). Conversely, a low level of LCC adoption means that public organizations are planning to adopt this approach but have never implemented it. We then focus on the multiple barriers against LCC by considering their overall intensity (i.e., high or low).

\section{Profile 1: Passive public institutions not exploiting LCC opportunities}

This profile is represented by public institutions that are not currently implementing LCC (low LCC adoption). However, in this case there are low barriers against its implementation, and thus this is a favourable context for its implementation - i.e., public institutions have internal resources to dedicate to LCC practices and it should be feasible to identify cost information to support LCC implementation. Nevertheless, public institutions are not exploiting this favourable context or the opportunities provided by LCC to identify and minimize costs throughout the life cycle of the purchase. However, some institutions have identified these opportunities and are planning to implement LCC - also based on new policies. Therefore, it is relevant to understand the potential evolution of organizations pertaining to this profile towards LCC internalization in this favourable context characterized by low barriers, as specified in Hypothesis $1(\mathrm{H} 1)$ and shown in Figure 3.

\section{Profile 2: Non-expert public institutions facing the LCC challenge}

Here, institutions do not have experience of adopting LCC. The context is not favourable due to high barriers against LCC implementation. It is a challenging context, as these public institutions have not implemented LCC so far and both internal and external issues are adverse. The turbulent environment has prevented companies from identifying LCC as a practice, thus in turn preventing them from being cost-efficient. Due to the current limited adoption of LCC in public organizations (Dragos and Neamtu, 2013), this represents another interesting profile to consider 
as a starting point for the internalisation of LCC, as specified in Hypothesis $2(\mathrm{H} 2)$ and shown in Figure 3.

\section{Profile 3: Efficient and proactive public institutions}

In this profile, LCC adoption is high as institutions are implementing it in a favourable context with low barriers. Public organizations can get the benefits of LCC through their learning and experience and are efficient in their implementation of LCC. The barriers are low as companies may have developed internal routines, dedicated specific resources, and identified external partners and external data sources. We investigate the likelihood that organizations will move towards this profile from profile $1(\mathrm{H} 1)$ and $2(\mathrm{H} 2)$, as depicted in Figure 3.

\section{Profile 4 - Public institutions in the middle of the "LCC journey"}

In this profile public institutions implement LCC in a complex context characterized by high barriers to implementation. Thus, they can implement LCC even in a nonfavourable context, while other institutions cannot. Nevertheless, high barriers still affect the adoption of LCC, thus limiting the effectiveness of results obtained from these organizations. We do not examine this profile, as our focus is to ascertain how GPP creates new LCC capabilities in the absence of previous LCC adoption and experience.

The profiles of LCC internalisation and the hypotheses investigated in the study are depicted in Figure 3. 


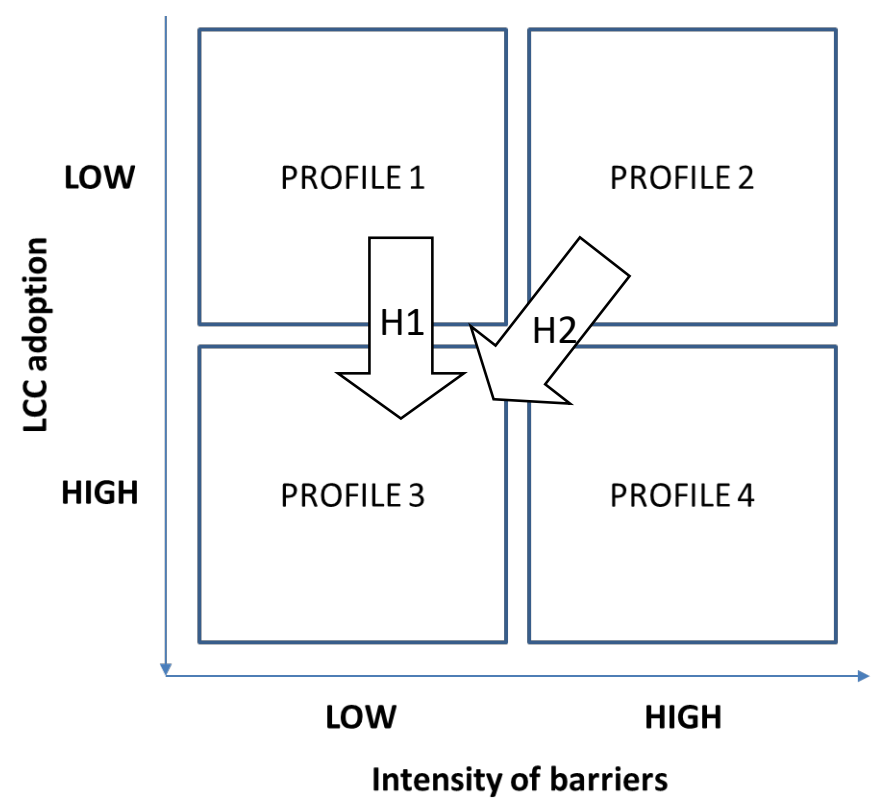

Figure 3 - The four profiles on LCC internalisation

\section{Methods}

\subsection{Data description}

To test our two hypotheses, we used data collected through the service contract conducted on behalf of the European Commission - the Directorate-General for the Environment - for the Development of a Life Cycle Costing (LCC) calculation tool project. The aim of this study was to design a tool to support administrations in procurement practices within the renewed normative framework of public procurement (EC Directive 2014/24/EU). Data were collected through an on-line questionnaire survey carried out in March-April 2015. The aim of the survey was to collect information on green public procurement and life cycle costing adoption by public organizations. To include as broad a sample as possible, we translated the questionnaire into four languages: Italian, English, French and Spanish. We invited many public organizations to complete the survey via e-mail, by contacting those responsible for procurement. Several channels and sources were used to disseminate the survey and define the sample, as identified in the EMAS (Eco-Management and Audit Scheme) register. We then selected all EMAS-registered European Public Administrations according to EU Regulation no. 1221/2009. The Regulation administers the voluntary Environmental Management System organizations can adopt to improve their management of environmental issues and performance (Testa et al., 2014). As the adoption of environmental certification has been identified as having positive effects on 
environmental responsibility (Handfield et al., 2002), we assume that public organizations with an EMAS certification would be concerned about the environment and would thus be more committed to green public procurement. As LCC is also considered a useful tool for reducing the environmental impact of public authority purchases, we also assumed that EMAS organizations would be more committed to the life cycle approach.

We then identified the public administrations that had recently participated in LIFE Programme European-funded projects on GPP, and organizations from the mailing list of the GPP Advisory Group. This is an expert group of representatives of the European Member States and other stakeholders, which provides support on GPP to the European Commission. We also contacted public administrations registered to receive the GPP News Alert, an initiative of the European Commission edited by the GPP Helpdesk. Public administrations that joined the 21 Local Agenda in Italy - the nonbinding, voluntarily sustainable development action plan of the United Nations - were also contacted. Approximately 1900 public organizations were thus approached.

Finally, we sent invitations to participate in the survey to public administrations with which we share networks through our involvement in European and national projects on environmental management. To obtain a high number of responses, the authors also posted the invitation on Linkedln.

The first section of the questionnaire included general data on the public organizations, such as their size (up to 10 employees, 11-250, or over 250) and scope, the type of organization (10 different types of public organizations were defined: see details in the next section) and the country of origin. The second section focused on GPP, and the third on LCC. All answers were collected anonymously.

The empirical analysis included a sample of 120 public organizations (corresponding to the final response rate), from $20 \mathrm{EU}$ and 10 non-EU countries. Details of the organizations and their countries of origin are included in Table 2 and in Figure 4.

\begin{tabular}{|l|l|l|l|l|l|}
\hline \multicolumn{3}{|c|}{$\begin{array}{c}\text { EU countries and sample } \\
\text { organizations }\end{array}$} & \multicolumn{2}{c|}{$\begin{array}{c}\text { Non-EU countries and } \\
\text { sample organizations }\end{array}$} \\
\hline Austria & 2 & Italy & 26 & Bangladesh & 1 \\
\hline Belgium & 10 & Lithuania & 2 & Bermuda & 1 \\
\hline Cyprus & 1 & Luxembourg & 1 & Canada & 2 \\
\hline Croatia & 3 & Netherlands & 1 & Iceland & 1 \\
\hline Denmark & 1 & Poland & 2 & Iraq & 1 \\
\hline
\end{tabular}




\begin{tabular}{|l|l|l|l|l|l|}
\hline France & 4 & Portugal & 4 & Norway & 1 \\
\hline Germany & 5 & Slovakia & 1 & $\begin{array}{l}\text { Republic of } \\
\text { Trinidad and } \\
\text { Tobago }\end{array}$ & 1 \\
\hline Greece & 1 & Spain & 16 & Switzerland & 2 \\
\hline Hungary & 1 & Sweden & 6 & Uganda & 1 \\
\hline Ireland & 1 & $\begin{array}{l}\text { United } \\
\text { Kingdom }\end{array}$ & 3 & USA & 1 \\
\hline
\end{tabular}

* The total number of organizations is 103 , as 17 out of 120 did not specify the country.

Table 2 - Number of organizations and countries

Regarding organization size, $54.2 \%$ of respondents belonged to institutions with over 250 employees, $35.8 \%$ to those with between 11 and 250 , and $7.5 \%$ to small public organizations ( $2.5 \%$ of the sample did not indicate the organization size).

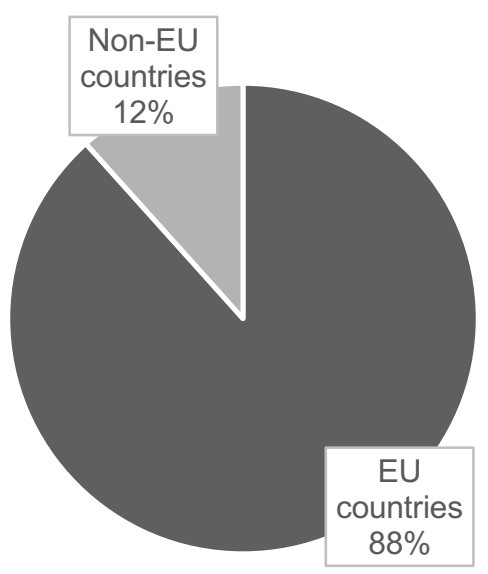

Figure 4 - Sample organizations: EU and Non-EU countries

\subsection{Variables and their measurements}

The dependent variable LCC internalisation was operationalised using two measurements. The first is an index on barriers to LCC adoption as perceived by public authorities. The construct is composed of 9 items (measured by a 5-point Likert scale), which reflect the extent to which a lack of these factors is perceived as a barrier for adopting LCC. The items are: information on internal and external costs; financial resources to implement the LCC approach; support from national and/or EU bodies; useful tools, guidelines, documents, laws, etc. that support public authorities in the implementation of LCC procedures; human resources; competence and knowledge; offers in compliance with cost information requested by the tenders; and reliable data 
sources for the evaluation of internal and external costs. Cronbach's alpha value was higher than the acceptability threshold of 0.7 (Nunnally, 1978), which indicates the reliability of a single-factor measure $(\alpha=0.83)$.

The second variable was categorical and measures the level of adoption of LCC within public authorities. Public managers replied to a question on the level of LCC adoption using a 4-point scale ranging from 1 (my organization has never implemented the LCC approach) to 4 (my organization regularly implements the LCC approach, i.e., in more than $50 \%$ of public tenders). In line with Boiral and Amara (2009), we developed four LCC internalisation perspectives by combining the two above-mentioned variables using their median values. The LCC perspective used in the survey was that defined by Article 68 of the 2014/24/EU Directive on Public Procurement.

The independent variable, experience on Green Public Procurement, was operationalized by combining the answers to two questions. The objective was to consider the two key experience characteristics (experience type and experience timing), as defined by the literature on organizational learning theory (Eggers, 2012). First, we measured the experience type on GPP, by asking respondents to specify the extent to which their organization had implemented GPP. Respondents replied using a 4-point scale ranging from 1 (my organization has never implemented GPP) to 4 (my organization implements regularly GPP, i.e., in more than $50 \%$ of public tenders). This measure enables us to consider both the breadth and the depth of experience. We measured GPP experience timing through the years of experience the public organization had of this environmental policy instrument. Respondents replied using a 4-point scale ranging from 1 (no experience) to 4 (9 years or more). The two items were combined into a single factor $(\alpha=0.79)$.

Finally, we controlled for an organization's size (i.e., the number of employees, according to three different classes) and type, which were central government/institution, regional government/institution, local government/institution, university/school, health organization, chamber of commerce or other public agency, publicly-owned company, research centre, monitoring/auditing and/or inspection body, and port authority. Over $30 \%$ of the sample belonged to central government or institution, $22 \%$ to local government or institution, and, $13 \%$ to regional government or institution. The other categories were not significantly represented.

The descriptive statistics and correlations for the variables are summarised in Table 3. 


\begin{tabular}{|c|c|c|c|c|c|c|c|c|}
\hline & Mean & Std. Dev. & Min & Max & $\begin{array}{c}\text { LCC } \\
\text { internalisatio } \\
\mathrm{n}\end{array}$ & GPP & $\begin{array}{c}\text { No. of } \\
\text { employe } \\
\text { es }\end{array}$ & $\begin{array}{c}\text { Organizatio } \\
\text { n type }\end{array}$ \\
\hline $\begin{array}{c}\text { LCC } \\
\text { internalisation }\end{array}$ & 2.425 & 1.300695 & 1 & 4 & 1.000 & & & \\
\hline GPP & 5.051282 & 1.920157 & 2 & 8 & 0.2780 & 1.000 & & \\
\hline $\begin{array}{c}\text { No. of } \\
\text { employees }\end{array}$ & 2.478632 & $\begin{array}{c}0.637861 \\
3\end{array}$ & 1 & 3 & 0.2459 & 0.0999 & 1.000 & \\
\hline $\begin{array}{c}\text { Organization } \\
\text { type }\end{array}$ & 3 & 2.543534 & 0 & 10 & -0.2417 & -0.3419 & -0.1616 & 1.000 \\
\hline
\end{tabular}

Table 3 - Descriptive statistics and correlations

\section{Results}

To test our hypotheses, we developed a model to investigate whether GPP can move an organization from a low level to a higher level profile in terms of LCC internalisation, thus considering Profile 1 (as defined in Hypothesis 1) and Profile 2 (as defined in Hypothesis 2) as starting points.

$\left(\log \left(P_{t}-P_{1-t}\right)\right)=\beta_{0}+\beta_{1}$ GPP $+\beta_{2}$ N. employees $+\beta_{3}$ Organization type, where $\beta(I=0,1,2,3)$ are the coefficients.

The dependent variable $\left(\log \left(P_{t}-P_{1-t}\right)\right)$ represents the ratio between the probability that a public organization belongs to a profile with a high level of LCC internalisation, and of it belonging to a profile with a low level of LCC internalisation.

Table 3 includes the results of the two profile models, estimating the influence of GPP variables in moving organizations from Profile 1 to Profile 3 (as defined in Hypothesis 1 ), and from Profile 2 to Profile 3 (as defined in Hypothesis 2). The effect of GPP experience in moving a public organization from a favourable context with low barriers (Profile 1 ) to a more proactive level of adoption (Profile 3 ) is not significant ( $\beta$ in Model 1 is $0.160, P=0.433$ ). Model 1 thus confirms that higher levels of GPP experience will not increase the likelihood that public organizations will develop LCC learning and capabilities.

The model estimations demonstrate that GPP experience can stimulate LCC learning and capabilities in organizations operating in an unfavourable context with high barriers. GPP experience thus helps public organizations to overcome barriers and supports them moving from Profile 2 to Profile 3 ( $\beta$ is 0.427 and significant at $95 \%$ in Model 2). We also used the models to estimate the role of geographical context in 
affecting the relation between GPP and LCC. We included a binary variable referring to EU and Non-EU countries, but as expected the effect was not significant due to a low variance of the dichotomous variable.

Finally, the organization's size and typology did not affect the relationship between LCC perspective and GPP adoption. Our method of measuring an organization's dimensions did not determine whether an organization's GPP performance was influenced by its size. Indeed, some studies have found that an organization's size does not affect the implementation of green procurement activities (Testa et al., 2016a; Walker and Brammer, 2012). To evaluate the robustness of the results, we verified that the cumulative odds ratio for any two covariates' values was constant across response categories (Peterson and Harrel, 1990). This assumption was positively tested through a likelihood ratio test, in which the null hypothesis means there is no variance in the models in terms of coefficients.

Collinearity was then analysed by computing the tolerance and variance inflation factors (VIFs) for variables. The results showed a VIF of less than 5 and low VIFs (< 2.0), confirming that multicollinearity is not a concern in the model (Kennedy, 2003).

We also checked for the existence of common method variance by performing Harman's single-factor post-hoc test (Podsakoff and Organ, 1986). Two distinct factors were identified with an eigenvalue higher than 1.0, and the largest explained about $32 \%$ of variance. As no single factor emerged, and the general factors did not account for the most of covariance among the variables (Steensma et al., 2005), we can confirm that common method variance was not an issue.

\begin{tabular}{|c|c|c|}
\hline Dependent variable & $\begin{array}{l}\text { Low LCC adoption \& } \\
\text { Low barriers/High LCC } \\
\text { adoption \& Low } \\
\text { barriers }\end{array}$ & $\begin{array}{c}\text { Low LCC adoption \& } \\
\text { High barriers/High LCC } \\
\text { adoption \& Low } \\
\text { barriers }\end{array}$ \\
\hline & $\begin{array}{l}\text { From Profile } 1 \\
\text { to Profile } 3 \\
\text { [Model 1] }\end{array}$ & $\begin{array}{c}\text { From Profile } 2 \\
\text { to Profile } 3 \\
\text { [Model 2] }\end{array}$ \\
\hline Independent variables & Coeff. $\beta$ & Coeff. $\beta$ \\
\hline Constant & $\begin{array}{c}\quad-19.392 \\
\text { (Std. Err 2784.144) }\end{array}$ & $\begin{array}{c}-19.080 \\
\text { (Std. Err 2784.195) }\end{array}$ \\
\hline GPP & $\begin{array}{c}0.160 \\
\text { (Std. Err 0.204) }\end{array}$ & $\begin{array}{c}0.427^{* *} \\
\text { (Std. Err 0.221) }\end{array}$ \\
\hline No. employees & $\begin{array}{c}0.451 \\
\text { (Std. Err 0.621) }\end{array}$ & $\begin{array}{c}0.408 \\
\text { (Std. Err 0.669) }\end{array}$ \\
\hline \multicolumn{3}{|l|}{ Organization type } \\
\hline $\begin{array}{c}\text { Central } \\
\text { government or } \\
\text { institution }\end{array}$ & $\begin{array}{c}17.218 \\
\text { (Std. Err 2784.194) }\end{array}$ & $\begin{array}{c}16.327 \\
\text { (Std. Err 2784.194) }\end{array}$ \\
\hline
\end{tabular}




\begin{tabular}{|c|c|c|}
\hline $\begin{array}{c}\text { Regional } \\
\text { government or } \\
\text { institution }\end{array}$ & $\begin{array}{c}16.113 \\
\text { (Std. Err 2784.194) }\end{array}$ & $\begin{array}{c}15.533 \\
\text { (Std. Err 2784.194) }\end{array}$ \\
\hline $\begin{array}{l}\text { Local government } \\
\text { or institution }\end{array}$ & $\begin{array}{c}15.819 \\
\text { (Std. Err 2784.194) }\end{array}$ & $\begin{array}{c}14.732 \\
\text { (Std. Err 2784.194) }\end{array}$ \\
\hline $\begin{array}{l}\text { University or } \\
\text { school }\end{array}$ & $\begin{array}{c}-0.325 \\
\text { (Std. Err 5682.66) }\end{array}$ & $\begin{array}{c}-1.263 \\
\text { (Std. Err 5682.66) }\end{array}$ \\
\hline $\begin{array}{c}\text { Health } \\
\text { organization }\end{array}$ & $\begin{array}{c}-0.147 \\
\text { (Std. Err 6761.087) }\end{array}$ & $\begin{array}{c}15.076 \\
\text { (Std. Err 8356.116) }\end{array}$ \\
\hline $\begin{array}{l}\text { Chamber of } \\
\text { Commerce or } \\
\text { other public } \\
\text { agency }\end{array}$ & $\begin{array}{c}-0.545 \\
\text { (Std. Er 6733.044) }\end{array}$ & $\begin{array}{c}16.835 \\
\text { (Std. Err 8373.096) }\end{array}$ \\
\hline $\begin{array}{l}\text { Publicly-owned } \\
\text { company }\end{array}$ & $\begin{array}{c}16.377 \\
\text { (Std. Er 2784.194) }\end{array}$ & $\begin{array}{c}15.688 \\
\text { (Std. Err 2784.194) }\end{array}$ \\
\hline Research centre & $\begin{array}{c}-0.133 \\
\text { (Std. Err 4151.847) }\end{array}$ & $\begin{array}{c}-1.144 \\
(\text { Std. Err } \\
4151.848)\end{array}$ \\
\hline $\begin{array}{l}\text { Monitoring/Auditi } \\
\text { ng or inspection } \\
\text { body }\end{array}$ & $\begin{array}{c}0.073 \\
\text { (Std. Err 11013.9) }\end{array}$ & $\begin{array}{c}17.391 \\
\text { (Std. Err 13977.23) }\end{array}$ \\
\hline Port authority & \multirow[t]{3}{*}{$\begin{array}{c}38.568 \\
\text { (Std. Err 39619.12) }\end{array}$} & \multirow[t]{3}{*}{$\begin{array}{c}38.012 \\
\text { (Std. Err 55960.68) }\end{array}$} \\
\hline $\begin{array}{c}\text { N. } 120 \\
\text { LR Chi square } \\
61.83\end{array}$ & & \\
\hline $\begin{array}{c}\text { Prob. > Chi } \\
\text { square } \\
0.0047 \\
\text { Pseudo R2 } \\
0.2093\end{array}$ & & \\
\hline
\end{tabular}

Table 4 - Estimated models of factors affecting the profiles on LCC internalisation

\section{Discussion}

The results confirm both hypotheses of our study, suggesting that GPP experience can stimulate LCC learning and capabilities in public organizations, by positively influencing the probability that a public organization will move from a context characterized by low LCC adoption to a more favourable LCC internalisation profile, but only in the specific case of adverse environmental contexts with high barriers to LCC. Our results are thus in line with the organizational learning perspective, confirming that the learning process can be influenced by the environmental context (Fiol and Lyles, 1985). The barriers to LCC (Schilling and Kluge, 2009), as one aspect of the context, are particularly influential and can pose challenges to the experience gained (March, 2010). The results of Model 1 support Hypothesis 1. The role of GPP in encouraging a public organization to move from Profile 1 , in which they adopt very 
few aspects of LCC but have some capabilities and learning in a context with low barriers, to Profile 3, is not significant. GPP experience cannot here be a valid driver of new additional learning or stimulate change towards LCC internalisation. As stated in the organizational learning theory, experience does not help stimulate new additional learning in a favourable, stable and predictable context. Organizations may already have a basic level of capability in terms of costing, and the GPP experience will not significantly increase the likelihood that they will include LCC in public tenders.

If, as the organizational learning theory suggests, organizations do not act to change and thus have a low incentive to learn (Fiol and Lyles, 1985) and continue with routine decisions and activities, inertia can set in. Contextual factors and barriers may impede the development of new capabilities and prevent change (Schilling and Kluge, 2009). The organizational learning theory suggests culture can significantly influence organizational action and change (Miles and Snow, 1978; Pfeffer, 1981). The culture may include shared beliefs, ideologies, and norms that are part of the organization and affect the actions it takes, thus limiting change and prevent new learning in organizations (Duncan, 1974; Fiol and Lyles, 1985). In this context in which public institutions rely on routine activities, as suggested by Hedberg (1981), excessive stability and static behaviour can result in stagnation instead of facilitating cognitive growth.

This study also finds that public organizations operating in an unfavourable context with high barriers and with limited LCC learning and capabilities are likely to evolve from a low level of LCC adoption to a higher level, due to greater experience of GPP. These findings support hypothesis 2. A high level of GPP experience enables public authorities to develop learning and capabilities through "using" a life-cycle perspective which can consequently produce a higher level of LCC integration in the purchasing process (Heijungs et al., 2013). Experience of GPP thus simultaneously contributes to LCC adoption and to reducing barriers against its implementation. Indeed, GPP acts as a facilitator towards LCC implementation in turbulent environments with high barriers, linking the environmental and economic components.

\section{Conclusion}


The results of the empirical multinomial logistic regression model in this study, in which an organizational learning perspective was taken, contribute to the theoretical knowledge on Sustainable Supply Management. Our study represents an initial attempt to integrate organizational learning into sustainable procurement, based mainly on the environmental component, as a mediator between supply management activities and economic results. This was initially investigated by Carter (2005) in the context of socially responsible purchasing. The study demonstrates under what conditions GPP and LCC, as environmental and economic dimensions of sustainability, can be integrated into public procurement, and the way they affect each other. Our study thus contributes to SSM studies by emphasizing the important interaction of economic and environmental values, which should not be perceived as separate. This follows Large and Gimenez Thomsen (2011), who stated that environmental commitment could generate competitive advantage, sustainable development and economic gains. The study also contributes to the organizational learning theory by confirming that the effect of experience on learning is affected by contextual barriers (Schilling and Kluge, 2009). The results show that GPP experience can encourage public authorities to adopt LCC, through the development of learning and capabilities in handling "life-cycle" related concepts and tools. Our study confirms previous findings that GPP is not simply an environmental criterion in procurement procedures (Testa et al., 2016a), but plays a key role by introducing the life cycle perspective and life cycle costing. Our study also explains the link between GPP experience and LCC learning by taking an organizational learning perspective. Like other findings on experience and learning, our results demonstrate that if antecedent conditions are similar in organizations, the experiences of similar tasks will be common (Haleblian and Finkelstein, 1999). Although they represent different concepts and tools, GPP and LCC are similar because both can be considered part of the sustainability culture of an organization. The environmental and economic dimensions of GPP and LCC respectively can be integrated within the context of sustainable purchasing and cannot be considered separate components of sustainability.

The study also confirms the organizational learning theory by demonstrating that GPP experience is not helpful in supporting organizations operating in a favourable context with low barriers. They are not incentivized to acquire new LCC knowledge, neither are they open to change towards LCC. Other contextual factors may prevent change and reduce their incentives to acquire new knowledge. However, one clear limitation of the 
study is that we did not investigate the role of other factors in stimulating new learning and change.

In addition, our research is based on assumptions derived from the model. Cross sectional data from a sample of public authorities was used to estimate whether GPP increases the probability to move from a less to a more favourable profile in terms of learning and adoption of LCC. The data for investigating a dynamic phenomenon within a public authority was thus derived from a static situation. A longitudinal study with a case study method could address this limitation, to reinforce and validate our conclusions and fully explore the internal dynamics that reveal the relation between GPP experience and LCC capabilities. Geographical contexts were not considered in our evaluation of the effects of GPP on LCC, and the four profiles of LCC adoption do not address intermediate levels in terms of the intensity of barriers. Both these issues are thus also limitations of our study.

Additional research is required to examine in more detail the role of environmental context and its effect on the organizational learning process. For example, understanding the need to avoid "organizational inertia" in too stable a context, and further exploring the role of other contextual environmental factors, may be of value. Further qualitative investigations aimed at understanding the organizational learning dynamics in public sustainable purchasing are also required, particularly when considering the social cost in LCC. Finally, as the results cannot be generalised to all of Europe, future research in this field could focus on public organizations located in other Member States, to more broadly appreciate the link between GPP and LCC.

\section{Acknowledgements}

The data collection was carried out within the service contract on behalf of the European Commission - the Directorate-General for the Environment, Directorate F, Strategy Unit F1 - Resource Efficiency and Economic Analysis - for the Development of a Life Cycle Costing (LCC) calculation tool project (service contract $\mathrm{N}^{\circ}$. 070201/2014/692192/SER/ENV.F.1)

The authors would like to thank the European Commission, and Studio Fieschi \& soci Srl as lead partner of the service contract. 


\section{References}

Ardit, D., Messiha, H.M., 1999. Life cycle cost analysis (LCCA) in municipal organizations. Journal of Infrastructure Systems, 5 (1), 1-10.

Argote, L., Miron-Spektor, E., 2011. Organizational learning: from experience to knowledge. Organization Science, 22 (5), 1123-1137.

Arja, M., Sauce, G., Souyri, B., 2009. External uncertainty factors and LCC: a case study. Building Research and Information, 37 (3), 325-334.

Asiedu, Y., Gu, P., 1998. Product life cycle cost analysis: state of the art review. International Journal of Production Research, 36 (4), 883-908.

Ashby, A., Leat, M., Hudson-Smith, M., 2012. Making connections: a review of supply chain management and sustainability literature. Supply Chain Management: An International Journal, 17 (5), 497-516.

Assaf, S.A., Al-Hammad, A., Jannadi, O.A., Saad, S.A., 2002. Assessment of the problems of application of life cycle costing in construction projects in Saudi Arabia. Cost Engineering-Ann Arbor then Morgantown, 44 (2), 17-22.

Berry, F.S., Chackerian, R., Barton, W., 1999. Reinventing Government: lessons from a state capital, in: Frederickson, H.G., Johnston, J. (Eds.), Public Management Reform and Innovation: research, theory and application. University Alabama Press, pp. 329-355.

Boiral, O., Amara, N., 2009. Paradoxes of ISO 9000 performance: a configurational approach. The Quality Management Journal, 16 (3), 36-60.

Bouwer, M., de Jong, K., Jonk, M., Berman, T., Bersani, R., Lusser, H., Nissinen, A., Parikka, K., Szuppinger, P., 2005. Green Public Procurement in Europe 2005 - Status Overview. Virage Milieu \& Management bv, Haarlem, the Netherlands.

Carter, C.R., 2005. Purchasing social responsibility and firm performance: The key mediating roles of organizational learning and supplier performance. International Journal of Physical Distribution \& Logistics Management, 35 (3), 177-194.

Carter, C.R., Rogers, D.S., 2008. A framework of sustainable supply chain management: moving toward new theory. International Journal of Physical Distribution \& Logistics Management, 38 (5), 360-387.

Chackerian, R., Mavima, P., 2000. Comprehensive Administrative Reform Implementation: Moving Beyond Single Issue Implementation Research. Journal of Public Administration Research and Theory, 11 (3), 353-377.

Cheng, W., Appolloni, A., D'Amato, A., Zhu, Q., 2018. Green Public Procurement, missing concepts and future trends-A critical review. Journal of Cleaner Production, 176, 770-784.

Chiurugwi, T., Udeaja, C., Hogg, K., 2010. Exploration of drivers and barriers to life cycle costing (LCC) in construction projects: professional quantity surveyors assessment, in Tizani, W. (Ed.), Computing in Civil and Building Engineering, Proceedings of the International Conference, Nottingham University Press, Nottingham, UK, Paper 108, p. 215.

Christmann, P., Taylor, G., 2006. Firm self-regulation through international certifiable standards: determinants of symbolic versus substantive implementation. Journal of International Business Studies, 37 (4), 863-878.

Costantino, N., Dotoli, M., Falagario, M.,Sciancalepore, F., 2012. Balancing the additional costs of purchasing and the vendor set dimension to reduce public procurement costs. Journal of Purchasing and Supply Management, 18 (3), 189-198. 
Damanpour, F., Schneider, M. 2009. Characteristics of innovation and innovation adoption in public organizations: Assessing the role of managers. Journal of Public Administration Research and Theory, $19(3), 495-522$.

Danneels, E., 2002. The dynamics of product innovation and firm competences. Strategic Management Journal, 23 (12), 1095-1121.

D'Incognito, M., Costantino, N., Migliaccio, G.C., 2015. Actors and barriers to the adoption of LCC and LCA techniques in the built environment. Built Environment Project and Asset Management, 5 (2), 202216.

Dodgson, M., 1993. Organizational learning: a review of some literatures. Organization Studies, 14 (3), 375-394.

Dragos, D., Neamtu, B., 2013. Sustainable Public Procurement: Life-Cycle Costing in the New EU Directive Proposal. European Procurement \& Public Private Partnership Law Review, 8 (1), 19-30.

Duncan, R.B., 1974. Modifications in decision structure in adapting to the environment: Some implications for organizational learning. Decision Sciences, 5 (4), 705-725.

Dutton, J.M., Thomas, A., 1984. Treating progress function as a managerial opportunity. Academy of Management Review, 9 (2), 235-247.

Eggers, J.P., 2012. All experience is not created equal: learning, adapting, and focusing in product portfolio management. Strategic Management Journal, 33 (3), 315-335.

Ellram, L., 1993. Total cost of ownership: elements and implementation. Journal of Supply Chain Management, 29 (3), 2-11.

European Commission, 2012. Green Public Procurement. A collection of good practices. Available at: http://ec.europa.eu/environment/ gpp last accessed: $13^{\text {th }}$ December 2016

European Commission, 2014. Directive 2014/24/EC of the European Parliament and of the Council of 26 February 2014 on public procurement. Official Journal of the European Union, 2014.

European Commission, 2016. Life-cycle costing. Available at: http://ec.europa.eu/environment/gpp/lcc.htm, last accessed: 13 ${ }^{\text {th }}$ December 2016.

Fiol, C.M., Lyles, M.A., 1985. Organizational learning. Academy of Management Review, 10 (4), 803813.

Giunipero, L.C., Hooker, R.E., Denslow, D., 2012. Purchasing and supply management sustainability: Drivers and barriers. Journal of Purchasing and Supply Management, 18 (4), 258-269.

Gormly, J., 2014. What are the challenges to sustainable procurement in commercial semi-state bodies in Ireland? Journal of Public Procurement, 14 (3), 395-445.

Haleblian, J., Finkelstein, S., 1999. The influence of organizational acquisition experience on acquisition performance: a behavioural learning perspective. Administrative Science Quarterly, 44 (1), 29-56.

Handfield, R., Walton, S., Sroufe, R., Melnyk, S., 2002. Applying environmental criteria to supplier assessment: a study in the application of the analytical hierarchy process. European Journal of Operational Research, 141 (1), 70-87.

Hasan, A., 1999. Optimizing insulation thickness for buildings using life cycle cost. Applied Energy, 63, 115-124.

Hedberg, B. (1981). How organizations learn and unlearn. In Nystrom, P.C., Starbuck, W.H., (Eds.), Handbook of Organizational Design, 1, Oxford University Press, New York, pp. 3-27.

Heijungs, R., Settanni, E., Guinée, J., 2013. Toward a computational structure for life cycle sustainability analysis: unifying LCA and LCC. The International Journal of Life Cycle Assessment, 18 (9), 1722- 
1733.

Heralova, R.S., 2014. Life Cycle Costing in the preparation of public works contracts. International Scientific Conference: People, Building and Environment (PBE 2014), October 2014, Kroměřiž, Czeck Republic, pp. 15-17.

Higham, A., Fortune C., James, H., 2015. Life Cycle Costing: evaluating its use in UK practice. Structural Survey, 33 (1), 73-87.

Holmqvist, M., 2004. Experiential learning processes of exploitation and exploration within and between organizations: an empirical study of product development. Organization Science, 15 (1), 70-81.

Horngren, C.T., Datar, S.M., Rajan, M.V., 2012. Cost accounting. A managerial emphasis. $14^{\text {th }}$ edition, Pearson Prentice Hall, Upper Saddle River, New Jersey.

Huber, G.P., 1991. Organizational learning: The contributing processes and the literatures. Organization Science, 2 (1), 88-115.

Hult, G.T.M., Hurley, R.F., Giunipero, L.C., Nichols, E.L., 2000. Organizational learning in global purchasing: a model and test of internal users and corporate buyers. Decision Sciences, 31 (2), 293325.

Hult, G.T.M., Ketchen, D.J., Nichols, E.L., 2003. Organizational learning as a strategic resource in supply management. Journal of Operations Management, 21 (5), 541-556.

Hunkeler, D., Lichtenvort, K., Rebitzer, G., 2008. Environmental life cycle costing. Crc press.

Hunkeler, D., Rebitzer, G., 2003. Life cycle costing: Paving the road to sustainable development? The International Journal of Life Cycle Assessment, 8, 109-110.

Iraldo, F., Nucci, B., De Giacomo, M.R., 2016. The relevance of Life Cycle Costing in Green Public Procurement. Economics and Policy of Energy and the Environment, 1, 91-109.

Lam., A., 2000. Tacit knowledge, organizational learning and societal institutions: an integrated framework. Organization studies, 21 (3), 487-513.

Large, R.O., Gimenez Thomsen, C., 2011. Drivers of green supply management performance: Evidence from Germany. Journal of Purchasing and Supply Management, 17 (3), 176-184.

Lawrence, P.R., Dyer, D., 1983. Renewing American industry. Free Press, New York.

Levitt, B., March, J.G., 1998. Organizational Learning. Annual Review of Sociology, 14, 319-340.

Lindholm, A., Suomala, P. 2004. The possibilities of Life Cycle Costing in outsourcing decision making, in Seppä, M., Hannula, M., Järvelin, A-M., Kujala, J., Ruohonen, M., \& Tiainen, T. (Eds.), Frontiers of eBusiness Research 2004, FeBR 2004, Conference Proceedings, Tampere, Finland.

Lindholm, A., Suomala, P. 2005. Present and future of Life Cycle Costing: Reflections from Finnish Companies. Liiketaloudellinen Aikakauskirja, 2, 282-292.

Lindholm, A., Suomala, P. 2007. Learning by costing. Sharpening cost image through life cycle costing? International Journal of Productivity and Performance Management, 56 (8), 651-672.

MacCormack, A., Verganti, R., lansiti, M., 2001. Developing products on 'Internet Time': the anatomy of a flexible development process. Management Science, 47 (1), 133-150.

March, J.G., 2010. The ambiguities of experience. Cornell University Press, Ithaca, NY.

Martinez-Sanchez, V., Kromann, M.A., Astrup, T.F., 2015. Life cycle costing of waste management systems: overview, calculation principles and case studies. Waste Management, 36, 343-355. 
Miles, R.E., Snow, C.C., (1978) Organizational strategy, structure and process, McGraw-Hill, New York.

Nikolaou, I.E., Loizou, C., 2015. The green public procurement in the midst of the economic crisis: is it a suitable policy tool? Journal of Integrative Environmental Sciences, 12 (1), 49-66.

Nunnally, J., 1978. Psychometric theory, McGraw-Hill, New York.

Ogden, J.M., Williams, R.H., Larson, E.D., 2004. Societal lifecycle costs of cars with alternative fuels/engines. Energy Policy, 32 (1), 7-27.

Olubodun, F., Kangwa, J., Oladapo, A., Thompson, J., 2010. An appraisal of the level of application of life cycle costing within the construction industry in the UK. Structural Survey, 28 (4), 254-265.

Oruezabala G., Rico, J.C., 2012. The impact of sustainable public procurement on supplier management: the case of French public hospitals. Industrial Marketing Management, 41 (4), 573-580.

Parikka-Alhola, K., 2008. Promoting environmentally sound furniture by green public procurement. Ecological Economics, 68 (1), 472-485.

Peterson, B., Harrell, F.E., 1990. Partial proportional odds models for ordinal response variables. Applied statistics, 39 (2), 205-217.

Pfeffer, J., 1981. Management as symbolic action: The creation and maintenance of organizational paradigms, in: Cummings, L.L., Sbaw, B.M., (Eds.), Research in organizational behaviour, 3, JAI Press, Greenwich, CT, pp.1-52.

Podsakoff, P.M., Organ, D.W., 1986. Self-reports in organizational research: Problems and prospects. Journal of Management, 12 (4), 531-544.

Preuss, L., Walker, H., 2011. Psychological Barriers in the Road to Sustainable Development: Evidence from Public Sector Procurement. Public Administration, 89 (2), 493-521.

PWC- PricewaterhouseCoopers, 2009. Collection of statistical information on Green Public Procurement in the EU. Report on data collection results. Amsterdam.

Renda, A., Pelkmans, J., Egenhofer, C., Schrefler, L., Luchetta, G., Selçuki, C., Ballesteros, J., Zirnhlet, A.C., 2012. The Uptake of Green Public Procurement in the EU27. Main Report. Centre for European Policy Studies (CEPS) and College of Europe (CoE), 29 February 2012.

Salvato, C., 2009. The contribution of event-sequence analysis to the study of organizational routines, in: Becker, M.C., Lazaric, N. (Eds.), Organizational routines: advancing empirical research. Edward Elgar Publishing.

Schilling, J., Kluge, A., 2009. Barriers to organizational learning: an integration of theory and research. International Journal of Management Reviews, 11 (3), 337-360.

Schneider, L., Wallenburg, C.M., 2012. Implementing sustainable sourcing - Does purchasing need to change? Journal of Purchasing \& Supply Management, 18 (4), 243-257.

Steensma, H.K., Tihanyi, L., Lyles, M.A., Dhanaraj, C., 2005. The evolving value of foreign partnerships in transitioning economies. Academy of Management Journal, 48 (2), 213-235.

Swaffield, L.M., McDonald, A.M., 2008. The contractor's use of life cycle costing on PFI projects. Engineering, Construction and Architectural Management 15 (2), 132-148.

Testa, F., Annunziata, E., Iraldo, F., Frey, M., 2016a. Drawbacks and opportunities of green public procurement: an effective tool for sustainable production. Journal of Cleaner Production, 112 (3), 18931900.

Testa F., Grappio P, Gusmerotti N.M., Iraldo, F., Frey, M., 2016b. Examining green public procurement using content analysis: existing difficulties for procurers and useful recommendations. Environment, Development and Sustainability, 18 (1), 197-219 
Testa, F., Rizzi, F., Daddi, T., Gusmerotti, N.M., Frey, M., Iraldo, F., 2014. EMAS and ISO 14001: the differences in effectively improving environmental performance. Journal of Cleaner Production, 68, 165173.

Tukker, A., Emmert, S., Charter, M., Vezzoli, C., Sto, E., Andersen, M.M., Geerken, T., Tischner, U., Lahlou, S., 2008. Fostering change to sustainable consumption and production: an evidence based view. Journal of Cleaner Production, 16 (11), 1218-1225.

Uttam, K., Balfors, B., Faith-Ell, C., 2013. Green public procurement (GPP) of construction and building materials, in: Pacheco-Torgal, F., Cabeza, L.F., de Magalhaes, A. (Eds.), Eco-efficient construction and building materials: Life Cycle Assessment (LCA), Eco-labelling and case studies, Woodhead Publishing Limited, pp. 166-195.

Walker, H., Brammer, S., 2012. The relationship between sustainable procurement and e-procurement in the public sector. International Journal of Production Economics, 140 (1), 256-268.

Walker, H., \& Phillips, W., 2008. Sustainable procurement: emerging issues. International Journal of Procurement Management, 2 (1), 41-61.

Weiss, H.M., 1990. Learning theory and industrial and organizational psychology, in: Dunnette , M. D., Hough, L. M. (Eds.), Handbook of industrial and organizational psychology. Palo Alto, CA, US: Consulting Psychologists Press, pp. 171-221.

White G.E., Ostwald P.F., 1976. Life cycle costing. Management Accounting, 57 (7), 39-42.

Woodward, D.G., 1997. Life cycle costing--theory, information acquisition and Application. International Journal of Project Management, 15 (6), 22-25. 